\title{
Mixed reaction greets new gene patent proposals from Brussels
}

London. Responding to growing public concern, the commission of the European Communities (EC) has revised its thinking on the protection of biotechnology inventions. In particular, the commission wants member countries to consider ethical questions in granting patents on living animals, and to exempt farmers from paying licence fees on genetically engineered seeds grown for their own purposes from purchased stocks. The commission has also proposed that no patents be issued on genes (and thus, by implication, on fragments of genes) whose biological function is unknown.

Despite reservations from some quarters, the second and third of these proposals are likely to find widespread support. Farmers throughout Europe have sought an exemption from rules that would undermine what has traditionally been considered a 'farmer's privilege', namely the right to produce seeds from one crop to sow on the next year. Scientists have strongly opposed actions by the National Institutes of Health to obtain patents on lengths of DNA sequences even though their function is not known; such a move, they assert, could undermine the Human Genome Project.

The fate of the first proposal is less predictable. Although animal-rights groups say that it improves on earlier proposals by the commission, many claim that the language is still inadequate. In particular, they argue that only a minimal demonstration of the human value of a transgenic animal would be needed for a patent.

The new directive, now being circulated, would bring into line the existing patent policies of the EC's 12 member states. The first version of the directive, published in October 1988, was widely considered to favour the biotechnology industry.

The revised proposals follow stormy debate in the European Parliament, where support was strong for the 'farmers' rights' exemption. There has also been widespread controversy over the decision by the European Patent Office to reject moral arguments against the patenting of Harvard University's Oncomouse (see Nature 361, 103; 1993).

In revising its original proposal for a directive, the Commission has included a paragraph that would ban three types of inventions or discoveries. For example, it states explicitly that no patents can be issued on the human body "or parts of the human body per se". This would not exclude patents on parts of the body (for example cell lines) capable of functioning outside the body. In contrast, however, the directive adds that "it goes without saying" that a patent could not be granted on, for example, "a human gene neither the function of which nor the protein for which it codes is known".

Who gets European biotechnology patents?

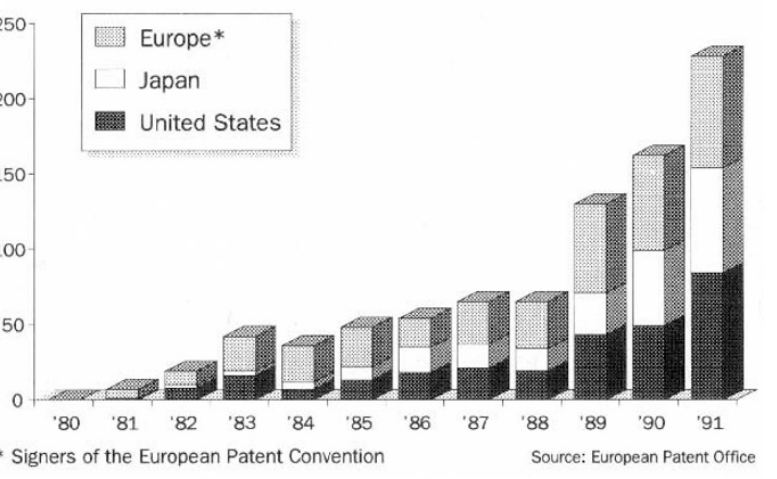

British patent experts say that this restriction, if adopted, would prohibit patents on cDNA fragments of unknown function.

The second proposed exclusion would be on processes for modifying the genetic identity of the human body "for a nontherapeutic purpose which is contrary to the dignity of man". Commission officials explain that the language has been carefully chosen to provide protection against what they describe as the "spectre of eugenics", while at the same time allowing patents to be granted for somatic gene therapy.

There is also language, completely missing from the earlier draft, stating that patents cannot be granted on "processes for modify-

\section{UK gene therapy gets go-ahead}

London. The British government this week is expected to give the green light to gene therapy experiments by announcing the creation of a new review board to oversee all such experiments. The work of the main board will be supported by advice from specialist committees set up to consider technical aspects of the research involved.

The long-awaited decision is based on the recommendations last January of a committee headed by Sir Cecil Clothier that concluded that there was no ethical objections to somatic gene therapy, but suggested a moratorium on germline therapy. ing the genetic identity of animals which are likely to inflict suffering or physical handicaps without any benefit to man or animal".

Commission officials believe that patent law is not the appropriate means to protect animals used in research. They say that this paragraph, patterned on a clause in the European Patent Convention that precludes patents on inventions considered to be against public morality, means that a patent cannot be issued on an invention which inflicts suffering on an animal "unless it may be beneficial [to humans]".

Animal rights groups say that this wording remains an unacceptable compromise. "I am very disappointed", says Peter Stevenson, research director of Compassion in World Farming, one of the groups that organized a protest earlier this month. "On first look, it appears to retain the morality clause of the European Patent Convention. But from a legal point of view, including the phrase 'without benefit to man or animal' makes everything else worthless, since all that an applicant would have to do would be demonstrate a potential benefit to man."

At present, EC member states are gathering comments on the directive before deciding how to proceed. Continued protests from animal rights groups are likely to resurface when the new directive is discussed at the Council of Ministers next month particularly because the presidency of the Council is held by Denmark, home to some of the most vocal protests.

Commission officials hope that the new directives will be adopted by the Council of Ministers and become law within nine months. On past experience, this timing seems highly optimistic. David Dickson
Although there is not expected to be a rush to carry out gene therapy experiments - some British researchers claim that the medical profession is much more conservative in its approach to new disease treatments than its counterpart in the United States - several research teams are still keen to start work. In particular, protocols have been prepared for research into the possible treatment for cystic fibrosis sufferers, and for research on transplanting bone marrow cells containing a manipulated adenosine deaminase (ADA) gene.

David Dickson 